\author{
Konrad Czarnecki \\ Uniwersytet Łódzki \\ k.czarnecki1990@gmail.com
}

\title{
"The war of the words": Historia Brytyjskich Indii w ujęciu neoliberalnym i marksistowskim
}

Streszczenie: Ponad 400 lat brytyjskiej dominacji nad około jedną czwartą powierzchni i ludności świata, przyczyniło się do powstania nowych państw i narodów. Współczesna geopolityka została natomiast ukształtowana w dużym stopniu przez zjawisko „anglobalizacji". Wielu badaczy kolonializmu nie potrafi jednak zająć jednoznacznego stanowiska wobec skutków brytyjskiej polityki kolonialnej. Dla jednych oznaczała ona szansę na rozwój podbitych kolonii, dla drugich zaś ich upadek. Niniejszy artykuł przedstawia historię Indii Brytyjskich w XIX wieku w ujęciu liberalnym i marksistowskim. Środowisko neoliberalne reprezentuje brytyjski historyk Niall Ferguson, który w swojej publikacji Imperium: Jak Wielka Brytania zbudowała nowoczesny świat dostrzega jedynie same zalety kolonizacji. Autor celowo pomija błędy brytyjskiej administracji. Mike Davis natomiast, reprezentujący środowisko marksistowskie, w swojej książce Late Victorian Holocausts. El Nino Famines and the Making of the Third World jednoznacznie krytykuje imperializm brytyjski. Artykuł jest więc próbą przybliżenie dwóch odmiennych stanowisk badaczy na temat oceny Imperium Brytyjskiego w Indiach.

Ponad 400 lat brytyjskiej dominacji nad około jedną czwartą powierzchni i ludności świata, przyczyniło się do powstania nowych państw i narodów. Współczesna geopolityka została natomiast ukształtowana w dużym stopniu przez zjawisko „anglobalizacji”. Wielu badaczy kolonializmu nie potrafi jednak zająć jednoznacznego stanowiska wobec skutków brytyjskiej polityki kolonialnej. Dla jednych oznaczała ona szansę na rozwój podbitych kolonii, dla drugich zaś ich upadek. Niniejszy artykuł przedstawia historię Indii Brytyjskich w XIX wieku w ujęciu neoliberalnym i marksistowskim. Środowisko neoliberalne reprezentuje brytyjski historyk Niall Ferguson, który w swojej publikacji Imperium. Jak Wielka Brytania zbudowała nowoczesny świat dostrzega jedynie same zalety kolonizacji. Autor celowo pomija błędy brytyjskiej administracji. Mike Davis natomiast, 
reprezentujący środowisko marksistowskie, w swojej książce Late Victorian Holocausts. El Niño Famines and the Making of the Third World jednoznacznie krytykuje imperializm brytyjski. Artykuł jest więc próbą przybliżenie dwóch odmiennych stanowisk badaczy na temat oceny Imperium Brytyjskiego w Indiach.

Kolonializm jako zjawisko historyczne pojawił się już w XV wieku. Był on następstwem wielkich odkryć geograficznych, zapoczątkowanych przez hiszpańskich oraz portugalskich żeglarzy. Nowy Świat zdominowany został przez podróżników iberyjskich. Najlepszym tego dowodem była wydana 4 maja 1493 roku przez papieża Aleksandra VI (1431-1503) Bulla Inter Caetera, z łac. „pośród innych” (Winniczuk, 1997: 523). W myśl papieskiego postanowienia ziemie zdobyte $\mathrm{w}$ okresie wielkich odkryć geograficznych zostały podzielone między Hiszpanię i Portugalię wzdłuż 38 południka. Pod auspicjami Hiszpanów znalazły się obie Ameryki (z wyłączeniem terenów dzisiejszej Brazylii), natomiast Portugalczycy przejęli kontrolę nad Brazylią i zdobyczami w Afryce (La Nouveau Monde. Bulle Inter caetera du 4 mai 1493). Taki podział pozaeuropejskiego świata trwał do końca XVI wieku, kiedy to Francja, Niderlandy i Anglia zakwestionowały iberyjski monopol kolonialny oraz same włączyły się do wyścigu o Nowy Świat. System kolonialny stworzony przez Europejczyków zaczął przechodzić głębokie transformacje dopiero po II Wojnie Światowej. Osłabione działaniami wojennymi metropolie nie posiadały odpowiednich środków i pieniędzy na to, by utrzymywać kolonie. W związku $\mathrm{z}$ tym w latach 50. XX wieku nastąpił rozpad największych mocarstw imperialnych - brytyjskiego i francuskiego. Kwestia oceny spuścizny kolonializmu natomiast nadal pozostaje sporna.

Dyskusja pomiędzy historykami kolonializmu stanowi integralną część rozważań niniejszej pracy, będącej analizą dwóch przeciwstawnych opinii. Tytuł pracy - „the war of the words" jest trawestacją tytułu książki angielskiego badacza Nialla Fergusona (1964) - The War of the World. History's Age of Hatred. Poniższy artykuł ma na celu ukazać dwa przeciwstawne stanowiska: wspomnianego Fergusona w Imperium. Jak Wielka Brytania zbudowała nowoczesny świat oraz Mike’a Davisa (1946) w Late Victorian Holocausts. El Niño Famines and the Third World. Badacze bowiem ukazują całkiem odmienną interpretację brytyjskiego kolonializmu.

Definicja neoliberalizmu została sformułowana w XVIII wieku przez francuskich fizjokratów ${ }^{1}$ i znana była wówczas jako leseferyzm (z franc. laissez faire - „pozwólcie działać”). Najpełniej jednak leseferyzm był realizowany w XIX-wiecznej Anglii. Liberalizm uznaje prymat wolności jednostki nad instytucjami politycznymi. Fundamentalnym założeniem neoliberali-

\footnotetext{
${ }^{1}$ Zwolennicy teorii ekonomicznej głoszącej, że praca i rolnictwo są jedynymi źródłami bogactwa państwa.
} 
zmu jest własność prywatna oraz rządy prawa oparte na mechanizmie działania wolnego rynku. Według leseferystów należało podjąć wszelkie kroki polityczne i ekonomiczne, by gospodarka została całkowicie zdominowana przez wolny rynek. Państwo natomiast powinno ograniczyć się do odgrywania roli nocnego stróża, czyli strzec, wspomnianych wcześniej, podstawowych zasad gospodarki: wolnego rynku i własności prywatnej. Z założenia państwo pełni funkcję pomocniczą, a nie nadrzędną w stosunku do obywateli. Ponadto według Adama Smitha (1723-1790)2 państwo powinno zapewnić obywatelom poczucie ich bezpieczeństwa (obrona narodowa). Zdaniem neoliberalistów (a w XIX wieku leseferystów) człowiek nie kieruje się tylko chęcią zdobycia korzyści materialnej (homo oeconomicus). ${ }^{3}$ Za podstawę swego istnienia neoliberalizm uznaje m.in.: swobodę zawierania umów, wolny rynek, ograniczenie wydatków państwa na cele socjalne, wzrost znaczenia przedsiębiorstw. Społeczeństwo natomiast cechuje wolność w wyrażaniu myśli i poglądów, tolerancja oraz pluralizm ${ }^{4}$.

Wielu badaczy kolonializmu nie potrafi zająć jednoznacznego stanowiska wobec efektów działań Brytyjczyków na Półwyspie Indyjskim. Dla jednych brytyjska kolonizacja oznaczała rozkwit podbitych kolonii, dla drugich zaś ich upadek. Wśród zwolenników teorii o pozytywnych skutkach kolonizacji czołowe miejsce zajmuje Niall Ferguson, jeden z najbardziej kontrowersyjnych współczesnych historyków. Angielski badacz zaliczany jest do grona historyków kontrafaktycznych, czyli tworzących alternatywne scenariusze historyczne. Obecnie współpracuje z Uniwersytetem w Harvardzie, Uniwersytetem Oxfordzkim oraz Uniwersytetem w Stanford. Niall Ferguson, co warto zauważyć, sympatyzuje z amerykańskimi konserwatystami. Uznaje on, że Stany Zjednoczone Ameryki w ostatnich dekadach XX wieku zyskały pozycję światowego przywódcy i wykazują wiele cech tradycyjnych imperiów (Woyke). Poglądy Nialla Fergusona na temat gospodarki wolnorynkowej bliskie są prawicowemu ugrupowaniu amerykańskiej sceny politycznej, stąd też tak wielkie zainteresowanie i sympatia ze strony amerykańskich konserwatystów w stosunku do poglądów angielskiego badacza.

Analizując stanowisko Fergusona w książce Imperium: Jak Wielka Brytania zbudowała nowoczesny świat należy zwrócić uwagę na tytuł jego publikacji. Autor celowo nie użył znaku zapytania, ale kropki. Historyk nie pyta, nie stawia hipotez i nie próbuje skłonić do dyskusji na temat roli

\footnotetext{
${ }^{2}$ Szkocki filozof, jeden z najwybitniejszych badaczy kapitalizmu i liberalizmu.

${ }^{3}$ Koncepcja Johna Stuarta Milla zakładająca, że człowiek, jako istota racjonalna, dąży jedynie do osiągania zysków i ich całkowitej maksymalizacji.

${ }^{4}$ Sytuacja, w której jednostka lub różne grupy społeczne mogą wyrażać swoje poglądy i bronić swoich praw.
} 
Wielkiej Brytanii w kreowaniu wizerunku obecnego świata. Przeciwnie, stawia on śmiałe tezy dotyczące wkładu Imperium Brytyjskiego w tworzenie współczesnego ładu światowego. Jego zdaniem Anglia stworzyła nowoczesny świat, a więc zależność Imperium - nowoczesny świat nasuwa jeden konkretny wniosek: gdyby nie Korona Brytyjska, dzisiejszy świat nie mógłby istnieć i funkcjonować tak, jak teraz. W jego ocenie Wielka Brytania nie była imperialistycznym mocarstwem, lecz liderem $\mathrm{w}$ modernizacji zacofanych państw Trzeciego Świata.

Ferguson uważa, że Imperium Brytyjskiego nie stworzyła kolonialna polityka Londynu, ale brytyjscy piraci łupiący hiszpańskie zdobycze w rejonie Karaibów. W rozdziale „Dlaczego Wielka Brytania?” możemy między innymi przeczytać, że:

w grudniu 1663 roku Walijczyk imieniem Henry Morgan przepłynął 500 mil przez Karaiby, aby dokonać spektakularnego ataku na hiszpański przyczółek zwany Gran Grenada [...] taki właśnie był początek imperium Brytyjskiego [...] Morgan i jego druhowie „korsarze” byli złodziejami, próbującymi skraść dochody czyjegoś imperium (Ferguson, 2007: 23).

Brytyjski badacz podkreśla również, że twórcami imperium jako podmiotu politycznego nie byli Anglicy, lecz inne narody. Brytyjczycy przejęli istniejący system imperialny i udoskonalili go: „Brytyjczycy nie byli bowiem pierwszymi twórcami imperium [...] Byli imperialnymi naśladowcami” (Ferguson, 2007: 19). Tym, co motywowało Wielką Brytanię do odkrywania nowego świata była chęć zdobycia złóż srebra i złota. Powiększenie swojego terytorium było początkowo kwestią drugoplanową.

Ferguson twierdzi, iż ważnym powodem, dla którego Brytyjczycy rozpoczęli swój podbój świata, była słabość do słodyczy (sic!). Na spotkaniu z polskimi czytelnikami (wrzesień 2007), poproszony przez prowadzącego spotkanie o ustosunkowanie się do powszechnie przyjętej opinii, potępiającej kolonializm, odpowiedział:

Imperium Brytyjskie rozszerzało się, ponieważ Brytyjczycy chcieli mieć więcej używek - nikotyny albo kofeiny. A przede wszystkim cukru. [...] Brytyjczycy mieli więcej energii niż ktokolwiek inny na świecie poprzez to, że żarli cukier. Źle odżywieni mieszkańcy Indii czy Chin nie mieli szans w porównaniu z grupą wielkich, potężnych Brytyjczyków (Włodek-Biernat).

Ten fakt oczywiście nie zdecydował jeszcze o imperialnej pozycji Wielkiej Brytanii. Główną motywacją podbojów kolonialnych Brytyjczyków, zdaniem Fergusona, okazała się chęć szerzenia idei wolnego handlu i angielskiego prawa (Włodek-Biernat), a urzeczywistnieniem tych idei była Brytyjska Kompania Wschodnioindyjska. Chęć posiadania przez Anglików złóż cennych kruszców czy monopolu na produkty deficytowe w Europie 
(kawa, herbata, cukier), w połączeniu ze sprawnie funkcjonującą angielską flotą i portami morskimi w różnych częściach świata, sprawiły, że Wielka Brytania zdeklasowała inne europejskie potęgi zamorskie i stała się liderem aspirującym o tytuł przyszłego mocarstwa.

W rozdziale zatytułowanym „Misja” brytyjski badacz opisuje zjawisko romantycznego mesjanizmu obecnego w świadomości społeczeństwa brytyjskiego w XVIII wieku. Według założeń mesjanizmu (nawiązującego do judaistycznej koncepcji Mesjasza-Zbawiciela) wybitna jednostka lub cały naród ma misję zbawienia świata. Z relacji Fergusona wynika, że społeczeństwo angielskie jest tym „mesjaszem”: „Brytyjczycy nie marzyli tylko o panowaniu nad światem, ale o zbawieniu go. Nie wystarczyło już im wyzyskiwanie innych ras; teraz celem stało się ich udoskonalanie" (Ferguson, 2007: 117). W jaki sposób Anglicy mieliby dokonać tego „zbawienia”? Historyk dalej pisze: „rdzenna ludność sama mogłaby wstrzymać wyzysk, ale ich kultury - zabobonne, zacofane i pogańskie - musiały zniknąć" (Ferguson, 2007: 117).

Celem wiktoriańskich misjonarzy było: „wprowadzenie stylu życia, który był przede wszystkim chrześcijański, ale również wyraźnie północnoeuropejski w swojej czci dla przemysłu i wstrzemięźliwości" (Ferguson, 2007: 118). Angielski historyk zauważa, że w wyniku działań misjonarzy Wielka Brytania „nastawiła się negatywnie do niewolnictwa” (Ferguson, 2007: 121), a do 1833 roku niewolnictwo zostało zdelegalizowane na terytorium Imperium Brytyjskiego. Anglia przestała handlować Afrykanami, a zaczęła eksportować swoją kulturę. Działania misjonarzy zyskały szerokie poparcie w społeczeństwie brytyjskim. Jednak, jak zauważa Ferguson, misje przyczyniły się do stworzenie „imperializmu ewangelickiego” (Ferguson, 2007: 125 ) i nie przypominały chrystianizacji, lecz anglicyzację.

Badacz w swojej pracy zauważa również, że oprócz Czarnego Lądu, angielscy misjonarze podejmowali próby chrystianizacji Indii. Działania wiktoriańskich misjonarzy napotkały opór w postaci hinduskich tradycji i zwyczajów. Jednym $\mathrm{z}$ tych zwyczajów była anumarana (sahamarana) ${ }^{5}$. Zwyczaj ten polegał na dobrowolnym spaleniu wdowy. Kobieta po śmierci męża, podejmując taką decyzję uznawana była w społeczności lokalnej, jako wierna i kochająca żona, a nawet określano ją mianem świętej.

Działalność misjonarska dążąca do chrystianizacji, czy jak pisze badacz anglicyzacji, nie była łatwa. Kulturę induską cechowała bardziej złożona rzeczywistość. Jej złożoność wynikała z rozbudowanych wierzeń, zwyczajów i tradycji. Rozpoczęło się więc, jak zauważa historyk, „zderzenie cywili-

${ }^{5}$ Anumarana (hind. umieranie po) lub sahamarana (hind. umieranie z) została nieprawidłowo określona przez Anglików jako sati (ang. suttee). Słowo sati oznacza wdowę, która spala się sama. 
zacji” (Ferguson, 2007: 138). Stworzona w celu zwalczania sati sekta Clapham ${ }^{6}$ doprowadziła do powołania kampanii działającej na rzecz wykorzenienia tej tradycji. Liczne wystąpienia przedstawicieli Sekty Clapham $\mathrm{w}$ brytyjskim parlamencie oraz wiele petycji podpisanych przez angielskich obywateli, doprowadziło do zniesienia w 1829 roku zwyczaju sati. Ostatecznie więc owe „zderzenie cywilizacji”, zdaniem Fergusona, dowodziło zwycięstwa angielskiej modernizacji nad niehumanitarną tradycją hinduską.

W rozdziale „Niebiańska rasa” historyk zwraca uwagę na istnienie tzw. Indian Civil Service. Kształcące się młode pokolenia Hindusów w duchu europejskiego oświecenia stawały się ambasadorami myśli i kultury angielskiej na subkontynencie. By potwierdzić słuszność swojej tezy odnoszącej się do tego, jak ważnym elementem polityki kolonialnej Wielkiej Brytanii było Indian Civil Service, Ferguson przytacza słowa Charlesa Travelyana (1870-1958) - członka Partii Liberalnej i Partii Pracy, który uważał, że ustanowienie: „naszego języka [angielskiego], naszych nauk i wreszcie religii doprowadzi do moralnej i intelektualnej odnowy narodu Indii" (Ferguson, 2007: 143). System angielskiej edukacji przyczynił się do wykształcenia wielu pokoleń Hindusów, a Korona w ten sposób dała ogromną szansę narodowi hinduskiemu. Co więcej, jak zauważa Ferguson, wielu młodych Hindusów dostrzegało tę szansę, dlatego „selekcja [do Indian Civil Service] musiała opierać się na prawdopodobnie najtrudniejszych egzaminach w historii [Imperium Brytyjskiego]" (Ferguson, 2007: 178). Dzięki funkcjonowaniu i popularności Indian Civil Service Brytyjczycy stworzyli nową probrytyjską elitę hinduską. Owa elita stała się pewnego rodzaju pośrednikiem pomiędzy Brytyjczykami a milionami Hindusów i nie tylko ułatwiała, ale także przyspieszała proces asymilacji autochtonów z Anglikami.

Należy pamiętać również o angielskiej technologii i jej wynalazkach telegrafie oraz kolei. Obecność Anglików na Półwyspie Indyjskim wpłynęła dynamicznie na rozwój indyjskiej infrastruktury. Włączenie Indii (poprzez kolej i telegraf) w system globalny było działaniem koniecznym dla Anglików, bowiem "Indie były strategicznym rdzeniem Imperium Brytyjskiego" (Ferguson, 2007: 195). Korona modernizując Indie i przyłączając je tym samym do światowej gospodarki, scalała i przybliżała do siebie swoje pozostałe kolonie. Nowoczesne, a także stabilne wewnętrznie Indie były potrzebne Brytyjczykom, „aby kontrolować całą półkulę, rozciągającą się od Malty aż po Honkong" (Ferguson, 2007: 161).

${ }^{6}$ Grupa anglikańskich reformatorów powstała na początku XIX wieku w Londynie. Sekta Clapham odegrała istotną rolę w budowaniu moralności społeczeństwa wiktoriańskiej Anglii. 
Mimo zwycięstwa Wielkiej Brytanii w I Wojnie Światowej w społeczeństwie brytyjskim pojawiły się pewne wątpliwości. Triumf okazał się pozorny, bowiem koszty tego zwycięstwa, jak podkreśla historyk, były największe w historii (Ferguson, 2007: 289). Londyn przeznaczył na działania wojenne najwięcej ze wszystkich stron konfliktu - 10 miliardów funtów. Uszczuplony budżet Imperium Brytyjskiego sprawił, że opinia publiczna również zmieniła swoje zdanie na temat finansowania i utrzymywania kolonii. Przyszłość Imperium była przesądzona.

Dlatego też angielski badacz twierdzi, że imperia nie trwają wiecznie: Imperium Aleksandra Wielkiego, Cesarstwo Rzymskie, a później Zachodniorzymskie i Bizancjum w pewnym momencie swego istnienia rozpadły się. Trudno bowiem rządzić tak ogromnym obszarem oraz ludnością go zamieszkującą. Imperium Brytyjskiemu było szczególnie trudno, bowiem nie tworzyło ono jednego tworu geograficznego, ale było „rozsiane” po całym świecie. To, co początkowo traktowane było, jako jego atut (ang. The empire on which the sun never sets) ${ }^{7} \mathrm{w}$ pewnym momencie stało się jego przekleństwem. Wynalezienie telegrafu i rozwój kolei tylko pozornie przybliżyło do siebie Londyn z koloniami. Faktycznie dzieliła je przepaść i to pod każdym względem. Anglicy podbijali ludy ukształtowane przez odmienny światopogląd, wychowane w różnym od brytyjskiego porządku prawnym czy religijnym. Mimo wielu różnic występujących pomiędzy Brytyjczykami a ludami przez nich podbijanymi, zdaniem Fergusona, wszelkiego rodzaju próby „anglobalizacji”8 przyniosły oczekiwane skutki. Jej najlepszym przykładem jest współpraca byłych kolonii brytyjskich w ramach członkowstwa w Brytyjskiej Wspólnocie Narodów.

Chcąc zamknąć rozważania nad Imperium Nialla Fergusona, należy odpowiedzieć na pytania: w jaki sposób i w jakim stopniu autor wraz ze swoją publikacją wpisuje się $\mathrm{w}$ idee neoliberalizmu? Badacz sam podaje gotową odpowiedź. Ferguson zwraca uwagę na to, iż Wielka Brytania, zdobywając nowe terytorium (siłą lub $\mathrm{w}$ drodze aliansu) narzucała wówczas wolny rynek oraz porządek prawny. Nie oznacza to, że prawo na tym obszarze nie istniało. Przeciwnie. Problemem było to, że nie był to porządek prawny $\mathrm{w}$ rozumieniu angielskim, a więc oświeconym, cywilizowanym. Ponadto Anglia chroniła swoich inwestorów, czego najlepszym przykładem była Kompania Wschodnioindyjska. Ferguson dalej wyjaśnia, że w historii ludzkości żadne inne mocarstwo nie umożliwiło swoim przedsiębiorstwom na skalę wręcz globalną swobodnego przepływu kapitału, towaru, usług

7 W XIX wieku Wielka Brytania nazywana była Imperium, nad którym nigdy nie zachodzi słońce ze względu na swoje rozległe terytorium. U szczytu swej potęgi Korona Brytyjska osiągnęła rozmiar $33 \mathrm{mln} \mathrm{km}^{2}$, czyli około 1/4 części globu.

8 Starania włączenia kolonii w system globalny, światowy pod auspicjami angielskimi. 
oraz ludzi. Korona Brytyjska była pierwsza. Dlatego też można ją uznać za prekursora globalizacji i neoliberalizmu. Ponadto autor wymienia pewnego rodzaju angielskie produkty eksportowe, które właśnie ujednoliciły i co najważniejsze - zmodernizowały „dziki świat”: język angielski - do dziś jest on językiem urzędowym $\mathrm{w}$ prawie wszystkich byłych koloniach, system prawny - znany w świecie anglosaskim jako Common law, religia - Anglia w opozycji do katolickiej Hiszpanii poczuła się w obowiązku szerzyć chrześcijaństwo (ale $\mathrm{w}$ duchu protestanckim), wreszcie Imperium przyniosło koloniom idee wolności i demokracji oraz wolny rynek

Trzeba pamiętać, że koniec epoki Imperium Brytyjskiego zbiegł się w czasie z dzieciństwem autora spędzonym w Kenii, o którym autor pisze tak: „mieliśmy własny parterowy domek, własną służącą, słabą znajomość suahili - poczucie niezachwianego bezpieczeństwa. Był to czas magiczny" (Ferguson, 2007: 10). I choć w jednym z wywiadów zaprzecza jakoby czuł tęsknotę za brytyjskim imperializmem - „Odrzucam więc oskarżenia, że jestem nostalgicznym brytyjskim imperialistą" (Bosacki), to przez takie określenia jak: „wszystko dzięki Imperium” (Ferguson, 2007: 11) czy „Imperium symbolizowało jasne światło" (Ibidem: 11) trudno uwierzyć w to, że poglądy Fergusona na temat imperialnej historii Wielkiej Brytanii są obiektywne. Brytyjski badacz przyjmuje stanowisko fanatyka, który bezgranicznie ufa $\mathrm{w}$ sens swoich ideałów. Podkreśla korzyści jakie dało ludom podbitym Imperium Brytyjskie (język, kultura, prawo), świadomie pomijając zbrodnie jakich dokonywali angielscy kolonizatorzy na autochtonach. Brak obiektywizmu i fakt, że Niall Ferguson zaliczany jest do grona historyków kontrafaktycznych sprawiają, że Imperium: Jak Wielka Brytania zbudowała nowoczesny świat należy postrzegać w kategorii eseju historycznego, a nie sprawiedliwej oceny brytyjskiego imperializmu.

Zdaniem marksistów imperializm jest $\mathrm{z}$ natury zjawiskiem negatywnym. W praktyce oznacza bogacenie się kapitalistycznej klasy pracodawców kosztem bogactwa wyprodukowanego przez inne państwa. Ponadto imperialny porządek świata nie wynikał z pokojowych aliansów, lecz ukształtował go nieustanny podbój. Zachodnioeuropejskie państwa zdobywały pozycję supermocarstwa często w drodze walki zbrojnej, która oznaczała zniewolenie strony pokonanej w konflikcie. Rozwój imperializmu oznaczał wykorzystywanie przez kapitalistów nie tylko klasy robotniczej w swoim kraju, ale również w kolonii. Robotnik w Indiach czy w Afryce był wykorzystywany podwójnie: przez rodzimą burżuazję oraz przez europejskich kapitalistów.

Obok negatywnych skutków kolonializmu, marksiści dostrzegają również jego pozytywne aspekty. Według nich kolonializm oznaczał kolejną fazę systemu kapitalistycznego, po którym miał nastąpić socjalizm. Uprzemysłowione państwa Europy stawiały sobie za cel włączenie innych państw 
o niższym stopniu industrializacji w globalną sieć zależności gospodarczych. Zwracając uwagę na pozytywne skutki imperializmu, warto także przypomnieć wypowiedź Karla Kautsky'ego (1854-1938) niemieckiego teoretyka socjalizmu, który określił imperializm jako:

produkt wysoko rozwiniętego kapitalizmu przemysłowego. Polega on [imperializm] na dążeniu każdego przemysłowego narodu kapitalistycznego do podboju i przyłączania do siebie coraz to większych obszarów agrarnych bez względu na to, jakie narody je zamieszkują (Rozdział VII. Imperializm jako odrębne stadium kapitalizmu).

Akcentowanie przez marksistów pozytywnych skutków polityki imperialnej nie wynikało z zafascynowania ideami XIX-wiecznego kolonializmu, ale oznaczało uznanie imperializmu jako narzędzia, które przybliży kraje nisko uprzemysłowione do rewolucji ekonomiczno-socjalistycznej. Imperializm dla marksistów, był zatem „celem, który uświęcał środki”.

Rozumiejąc, jakie jest podejście zwolenników marksizmu do zjawiska imperializmu, warto zwrócić uwagę na książkę Mikea Davisa - Late Victorian Holocausts: El Niño Famines and the Third World. Autor ocenia obecność brytyjską w Indiach inaczej niż Niall Ferguson. Davis (profesor Uniwersytetu Kalifornijskiego w Riverside) obwinia Koronę Brytyjską o stworzenie „Trzeciego Świata”. Globalizacja czy raczej „anglobalizacja”, jego zdaniem, przyniosła więcej strat niż zysków ludom podbitym przez Anglików. Historyk już w tytule swojej pracy stwierdza, że imperializm brytyjski przyczynił się negatywnie do budowania współczesnego świata. Określa angielskie rządy holokaustem, który kojarzony jest przede wszystkim z polityką i działaniami III Rzeszy. Autor opisuje skutki obecności brytyjskiej na Półwyspie Indyjskim. Jego zdaniem efektami rządów Korony były trzy klęski głodu, które dotknęły Indie w latach: 1876-1879, 1896-1897 i 1899-1902. Według Davisa w wyniku źle prowadzonej administracji połączonej z katastrofami głodu zmarło od 12,2 do 29,3 milionów mieszkańców Indii (Davis, 2002: 7). W opinii Brytyjczyków (a także Nialla Fergusona) śmierć tak wielu ludzi nie wynikała ze złego zarządzania, ale była wynikiem niesprzyjającego klimatu.

Mike Davis nie podziela zdania Fergusona. Zauważa, że klęski nie wynikały tylko i wyłącznie z niekorzystnego klimatu, ale ze złej organizacji. Sytuacje kryzysowe w Indiach były więc rezultatem nieudolnych działań politycznych. Gdyby Brytyjczycy podjęli odpowiednio wcześniej takie kroki jak: wprowadzenie embarga na eksport żywności, ulgi podatkowe oraz zniesienie obowiązku pracy w zamian za wydawanie racji żywnościowych, klęski na tak wielką skalę, zdaniem amerykańskiego badacza, dałoby się uniknąć.

Analizując stanowisko Mike’a Davisa, można śmiało wysunąć wniosek - autor w sposób jednoznaczny zaprzecza determinizmowi środowiskowe- 
mu, w myśl którego człowiek jest całkowicie uzależniony od działań natury, a każde zachowanie jednostki wynika z warunków dyktowanych przez środowisko. Amerykański historyk swoimi poglądami bliższy jest idei $\mathrm{XX}$-wiecznego posybilizmu środowiskowego nadal przyznającemu naturze nadrzędność, ale podkreślającemu, że człowiek ma wybór. Środowisko stwarza warunki do funkcjonowania człowieka, lecz to człowiek decyduje, w jaki sposób z tych warunków korzysta (Sadowski, 2009: 46-48). Nie do końca przekonywujące jest więc stanowisko apologetów Fergusona, uważających, że niekorzystny klimat Indii przyczynił się do klęski głodu. Jeśli natura jest tylko i wyłącznie odpowiedzialna za klęski głodu, to jak zatem wytłumaczyć istnienie przez wieki, przed pojawieniem się Brytyjczyków na subkontynencie, systemu rolnictwa, który potrafił wykarmić ludność subkontynentu? Przed przybyciem brytyjskich kolonizatorów na Półwysep Indyjski autochtoni potrafili przeciwdziałać negatywnym skutkom klimatu, w którym żyli od zawsze. Ponadto dynastia Mogołów, panująca przed angielskimi kolonizatorami, środki z podatków przeznaczała na modernizację ujęć wody oraz udzielała hinduskim chłopom ulg podatkowych na budowę systemów nawadniania:

urzędnicy lokalni wykazywali się znaczną wyrozumiałością, jeśli chodzi o naliczanie podatków. Do ich zwyczajowej praktyki należało zachęcanie chłopów do budowy studni przez oferowanie im odpowiednich zniżek. Przykładowo, w okręgu Ahmedabadu regularnie znoszono podatek na rabi (plony wiosenne), które zebrano dzięki istnieniu systemu nawadniania zasilanego przez nowo wybudowane studnie. Wakacje podatkowe były utrzymywane tak długo, aż wielkość zaoszczędzonej w ten sposób przez wieśniaków kwoty zrównała się z kosztem instalacji systemu (Davis).

To właśnie Brytyjczycy zniszczyli tę symbiozę człowieka z naturą. Obsesyjna chęć modernizacji Indii doprowadziła do widocznego regresu m.in. w dziedzinie rolnictwa. Podczas gdy Niall Ferguson zauważa, że pod koniec XIX-go wieku zaczął tworzyć się nowoczesny świat (pod auspicjami Londynu), a wraz z nim handel i wolny rynek, Davis podkreśla, iż dla Indii oznaczało to przejście do gospodarki towarowej. Dotychczasowe uprawy na własne potrzeby (substenance crops) zastąpiono uprawą przeznaczoną na eksport (cash crops). Wcześniej indyjscy chłopi uprawiali ryż, jęczmień i mogli wyżywić nimi siebie oraz rodzinę, ale wraz z przejściem na gospodarkę towarową zaczęli odchodzić od uprawy tradycyjnych zbóż i zaczęli uprawiać głównie bawełnę. Taka zmiana struktury upraw doprowadziła do załamania „stabilności żywnościowej” na subkontynencie, czego tragicznym skutkiem były trzy fale głodu na przełomie XIX i XX wieku.

Pierwsza fala głodu nawiedziła Madras (południowo-wschodnie Indie) w latach 1886-1889. Urzędujący wówczas wicekról Indii Lord Lytton 
(1831-1891) zabronił organizowania jakichkolwiek robót, by tym samym uniknąć dystrybucji żywności dla pracujących (Ibidem). W okresie jego rządów wydano w 1877 roku ustawę "The Anti-Charitable Contributions $A c t ”$, zakazującą „pod groźbą kary więzienia, stosowania prywatnych dotacji, które mogłyby mieć wpływ na rynek zboża" (Davis, 2002: 39).

Leseferystyczna polityka prowadzona przez Lyttona doprowadziła również do powstania obozów pracy, które, jak twierdzi Davis, w swojej specyfice przypominały te prowadzone przez nazistów w okresie II Wojny Światowej. Zdaniem dra Cornisha (krytyka angielskiej administracji) w brytyjskich obozach pracy miesięcznie umierała tak duża liczba ludzi, że odpowiadała ona 94 proc. średniej rocznej ilości zgonów w Indiach (Manbiot). Ponadto robotnicy otrzymywali tzw. pensję Tepmle’a, czyli określoną porcję żywnościową, która bliska była racji głodowej (Davis). Hinduscy chłopi, aby otrzymać (i tak już małą) porcję żywności, musieli udowodnić Brytyjczykom, że są w stanie pracować w zamian za żywność. Aby otrzymać żywność, głodujący musieli dosłownie przejść tzw. „test odległości”. Marsz na dystansie minimum 10 mil, czyli ponad 40 kilometrów dla chłopów, będących w stanie agonalnym, był ogromnym wysiłkiem. Człowiek albo umierał i przestawał być „problemem” dla Brytyjczyków (o ile kiedykolwiek nim był), albo, jeśli przeżył, udowadniał, że nadaje się do ciężkich prac (Davis, 2002: 43).

Obfite opady deszczu na przełomie września i października 1878 roku pozornie tylko złagodziły efekty suszy. Wilgotna ziemia i powietrze stały się idealnym środowiskiem do rozrodu komarów, które przenosiły malarię. Epidemia malarii zdziesiątkowała wykończonych suszą chłopów. Wycieńczeni Hindusi, zarażeni febrą, nie mieli siły walczyć z chorobą pustoszącą ich organizm, w wyniku czego umierali (Davis).

W latach 1896-1897 Indie dotknęła druga fala głodu. Tym razem nawiedziła ona Pendżab (północno-zachodnie Indie) i zachodnie prowincje. W przypadku tej katastrofy (zaledwie 10 lat po pierwszej fali głodu w Madrasie) oprócz bezczynności Brytyjczyków udział miał czynnik zewnętrzny. Ostatnia dekada XIX wieku przyniosła suszę, która nawiedziła Stany Zjednoczone Ameryki - jednego z głównych eksporterów zboża do Europy. Susza w Ameryce Północnej sprawiła, że ilość zboża była znacznie ograniczona. Popyt na nie wzrósł, a wraz z popytem cena zboża. W związku tym, większość zboża wyprodukowanego w Indiach przewożono do Europy. Rolnicy, którzy nie chcieli sprzedać zboża przedstawicielom firmy Ralley Brothers $^{9}$ byli przez nich bici. Ponadto zmiana na urzędzie wicekróla Indii

\footnotetext{
${ }^{9}$ Firma handlowa założona przez pięciu braci. Od 1851 roku prowadziła również działalność w Indiach w celu zakupu m.in. imbiru, saletry i kurkumy i sprzedaży tych towarów na rynkach europejskich.
} 
również nie przyniosła poprawy sytuacji w Indiach. Nowy wicekról Lord Elgin (1849-1917) był kontynuatorem niehumanitarnej polityki prowadzonej przez Lyttona. Leseferystyczne podejście Brytyjczyków wyrażał skrajny liberalizm i nieingerowanie państwa w wolny rynek, a pomoc ze strony Londynu oznaczałaby taką właśnie interwencję. Elgin, podobnie jak Lytton, nie widział uzasadnienia dla realnej pomocy. Następca Lyttona uważał, iż dystrybuując żywność głodującym, którzy nie musieliby pracować, władza zaczęłaby ingerować w rynek, a to oznaczałoby, że państwo przestałoby pełnić funkcję „nocnego stróża” (Winiarski, 2006: 105). Takie działania Brytyjczyków doprowadziły do śmierci około 6,5 miliona osób (Davis, 2002: 158). Ponadto poziom higieny, doprowadził do wybuchu pandemii dżumy roznoszonej przez pchły szczurów (Czarna śmierć). Davis przekazuje, że w wyniku klęski głodu i epidemii śmierć poniosło około 18 milionów ludzi (Davis, 2002: 152).

Kolejna, trzecia fala głodu dotknęła Indie w latach 1899-1902. Bezpośrednim powodem klęski była susza, która nawiedziła półwysep i objęła swym zasięgiem środkowe i zachodnie Indie. Sytuacja była o tyle trudna, ponieważ Indie nie poradziły sobie jeszcze ze skutkami dwóch poprzednich katastrof. Brytyjczycy swoim biernym działaniem nie ułatwiali Hindusom walki z głodem i siłami natury. Głodujący Hindusi otrzymali pomoc, która nadeszła z Ameryki. Farmerzy z Kansas (stan rolniczy w środkowej części Stanów Zjednoczonych Ameryki) oraz Indianie podarowali zboże głodującym wieśniakom z Indii. Zboże zostało jednak opodatkowane przez Brytyjczyków, co wywołało sprzeciw darczyńców, a także amerykańskiej opinii publicznej. Hindusi nie otrzymali żadnej pomocy z Londynu, który ograniczył się do wspomnianej wcześniej roli „nocnego stróża”. Dodatkowo wicekról Indii Lord Curzon (1859-1925) kontynuował dzieło swoich „niechlubnych” poprzedników. Robił wszystko, by nie pomagać głodującej społeczności. W zamian za to, z pieniędzy angielskich darczyńców, odrestaurował upadający Tadź Mahal (sic!) oraz wybudował pomnik Królowej Wiktorii w Kalkucie.

Jak zauważa Mike Davis w wyniku źle prowadzonej polityki Brytyjczyków w Indiach życie straciło miliony osób. Strona brytyjska obciążała winą niekorzystny klimat. Okazuje się jednak, że działania Korony wpisują się w założenia Thomasa Maltusa (1766-1834) twórcy tzw. pułapki maltuzjańskiej. Maltus w swojej pracy Prawo ludności zauważył pewną zależność: zasób surowców (m. in. zboża) nie rośnie współmiernie do rosnącej liczby ludności. Zbyt duża populacja umierała w wyniku niewystarczającej ilości żywności. Ci, którzy przeżyli uprawiali rolę i zwiększali ilość zboża (Ibidem: 32). Wraz ze wzrostem ilości wyżywienia, rosła liczba ludności i sytuacja znów się powtarzała. Wydaje się, że Brytyjczycy celowo nie przeciwdziałali skutkom pułapki maltuzjańskiej, która do pewnego 
stopnia rozwiązywała jeszcze jeden problem - eksplozję demograficzną. Najniższe warstwy społeczne oraz nietykalni ${ }^{10}$, widząc ewentualną brytyjską inicjatywę (w rzeczywistości jej nie było), mogliby przyzwyczaić się do „opiekuńczej” roli państwa. Londyn, chcąc się ustrzec przed kosztowną pomocą, postanowił nie podejmować żadnych działań:

doktryna utrzymująca, że w okresie klęski głodu biedni są uprawnieni do uzyskania pomocy [...] doprowadziłaby zapewne do twierdzenia, że pomoc tego typu należy im się cały czas. W ten sposób doszłoby do wypracowania systemu powszechnego wsparcia, którego wzięcie pod uwagę musiałoby wzbudzić w nas największe obawy. (Report of the Indian Famine Commission,1878, 1880: 59)

Oznaczało to wyrażenie zgody na śmierć ponad 10 milionów ludzi. Takie zachowanie angielskich kolonizatorów dało sygnał światu i samym poddanym Wielkiego Imperium Brytyjskiego, że czynnik ludzki jest ostatnim elementem polityki kolonialnej metropolii.

Podsumowując analizę Late Victorian Holocausts: El Niño Famines and the Third World Mike'a Davisa, nasuwa się jeden wniosek - autor jednoznacznie ocenia, a raczej krytykuje działania brytyjskiego imperializmu. Badacz świadomie $w$ tytule swojej pracy zaznacza wpływ czynnika zewnętrznego - El Niño. Jest to anomalia pogodowa powstająca w momencie osłabienia stałego i ciepłego wschodniego wiatru - pasat (Stasiak i Zaniewicz, 2006: 125) oraz podnoszenia się oceanicznych wód głębinowych - upwelling (Stasiak i Zaniewicz, 2006: 175). To zjawisko pogodowe otrzymało nazwę El Niño, czyli z języka hiszpańskiego „dzieciątko”, z powodu jego występowania w okresie świąt Bożego Narodzenia. Davis celowo w tytuł swojej rozprawy wplata faktor środowiskowy, by podkreślić pewną kwestię. Ma świadomość, że El Niño nie było czymś nowym - to proces trwający od zawsze i ciągle się powtarzający. Amerykański badacz ośmiesza w ten sposób nieudolność brytyjskiego aparatu władzy i sposób funkcjonowania administracji. Tragedii humanitarnej, jaką było El Niño dało się uniknąć. W wyniku fal głodu i epidemii zginęło, zdaniem Davisa „nawet 30 milionów [ludzi], nie są również przesadzone szacunki mówiące o 50 milionach ofiar" (Davis, 2002: 4). I co ważne, amerykański badacz podkreśla, że te miliony ludzi zginęły nie „poza obrębem nowoczesnego świata, ale w trakcie włączania na siłę w jego ekonomiczne i polityczne struktury" (Davis, 2002: 9).

Wobec powyższego widać, że Mike Davis nie tylko polemizuje z neoliberalną wizją historii Indii Brytyjskich Nialla Fergusona, ale w pewnym

10 Grupa ludzi w indyjskim systemie kastowym, należących do najniższych kast oraz tych, którzy znajdują się poza systemem. 
stopniu nawet ją ośmiesza i dyskwalifikuje za brak obiektywizmu. Neguje ją do tego stopnia, że książka Fergusona - Imperium: Jak Wielka Brytania zbudowała nowoczesny świat śmiało mogłaby przyjąć tytuł „Imperium: Jak Wielka Brytania zbudowała Trzeci Świat".

Imperium Brytyjskie w znacznym stopniu przyczyniło się powstania dzisiejszej sytuacji geopolitycznej. Ponad 400 lat kolonialnej dominacji Londynu determinowało działania nie tylko pozostałych państw europejskich, ale także tych położonych tysiące kilometrów od Wielkiej Brytanii. Skutki angielskiego monopolu imperialnego do dziś wywołują dyskusję pomiędzy historykami kolonializmu. Dla jednych badaczy kolonializm był zjawiskiem pozytywnym (np. Niall Ferguson), dla drugich zaś tylko negatywnym, którego skutki odczuwane są do dziś w państwach będących byłymi koloniami europejskimi (np. Mike Davis). Zdania historyków są diametralnie różne. Niniejsza praca jest więc próbą przybliżenia dwóch odmiennych stanowisk badaczy na temat oceny Imperium Brytyjskiego w ujęciu neoliberalnym i marksistowskim.

Niall Ferguson pomija negatywne skutki angielskiej obecności na subkontynencie, nobilitując politykę Londynu. Jego zdaniem kolonializm przyniósł przede wszystkim korzyści: system prawa, wolny rynek, edukację oraz idee oświeceniowe. Negatywne zjawiska, które towarzyszyły rządom brytyjskim Ferguson traktuje jak drobne potknięcia, które i tak są niczym wobec ogromu postępu jaki przynieśli ze sobą „cywilizowani” Europejczycy. Dla angielskiego badacza historia Indii Brytyjskich, jak również Afryki czy Australii, jest dowodem wyższości polityki angielskiego establishmentu. Koronie nie chodziło, zdaniem Fergusona, o wyzysk i całkowitą eksploatację kolonii, wręcz przeciwnie - jej celem była chęć włączenia zacofanych społeczeństw w polityczny i ekonomiczny system ogólnoświatowy. Dzisiejsza rzeczywistość międzynarodowa, oparta na zasadach kapitalizmu, powstała, według Fergusona, dzięki szerzeniu przez Imperium Brytyjskie w XIX wieku idei wolnego rynku. W książce angielskiego historyka można przeczytać, że: „bez rozprzestrzeniania się brytyjskiej władzy na świecie, struktury liberalnego kapitalizmu nie mogłyby skutecznie powstać w tak wielu różnych gospodarkach na całym świecie" (Ferguson, 2007: 327). Niall Ferguson stwierdza, że Wielka Brytania była prekursorem globalizacji, podkreślając jedynie korzyści jakie przyniósł kolonializm.

Mike Davis natomiast całkowicie zaprzecza wyidealizowanej wizji rządów brytyjskich. W swojej publikacji przedstawia angielskiego imperatora, który obsesyjnie i pod przymusem chce zmodernizować między innymi Indie. Subkontynent indyjski pod rządami Brytyjczyków stał się przede wszystkim spichlerzem Londynu. Anglia, chcąc budować swoją imperialną pozycję na arenie międzynarodowej, musiała zapewnić sobie monopol na 
eksport zbóż, by móc spekulować ich ceną na rynku światowym. Davis nie uzależnia całkowicie klęsk głodowych w Indiach od El Niño. Ta anomalia pogodowa występowała w tej części globu od zawsze. Amerykański badacz kładzie natomiast nacisk na fanatyczne przywiązanie Brytyjczyków do idei wolnego rynku. Katastrofy klimatyczne na subkontynencie były nieuniknione, ale ich skutki, zdaniem Davisa, można było w znacznym stopniu ograniczyć. Tym samym Davis opowiada się po stronie większości europejskich historyków, którzy twierdzą, że kolonializm przyczynił się do podziału współczesnego świata na bogatą Północ (Europa) i biedne Południe (m.in. Afryka).

Nie zważając na korzyści dla Starego Kontynentu ${ }^{11}$ jakie płynęły z europejskiej kolonizacji nowych lądów (ekspansja terytorialna, nowe rynki zbytu, źródło dostaw cennych kruszców), społeczność międzynarodowa potępiła kolonializm i określiła go mianem „zbrodni przeciwko ludzkości”:

Kolonializm doprowadził do rasizmu, dyskryminacji rasowej, ksenofobii i związanej z nią nietolerancji, [...] Afrykanie i ludzie pochodzenia afrykańskiego, azjatyckiego oraz inne narody autochtoniczne były ofiarami kolonializmu i wciąż cierpią z powodu jego konsekwencji. (cyt. za Ferguson, 2007: 7)

Deklaracja Międzynarodowej Konferencji przeciw rasizmowi, dyskryminacji rasowej i nietolerancji z 2001 roku bliższa jest więc stanowisku Mike’a Davisa i potwierdza słuszność jego argumentów. Społeczność międzynarodowa krytykuje kolonializm, a wszelkie ewentualne korzyści z niego wynikające uznaje za mniej istotne wobec ogromu ludzkiego cierpienia jakie wyrządził.

Mimo potępiających imperializm haseł głoszonych przez społeczność międzynarodową epoki postkolonialnej, nadal widoczny jest brak chęci zadośćuczynienia wyrządzonych krzywd ze strony byłych mocarstw europejskich. Stowarzyszenie takie jak Commonwealth, które zrzesza angielską metropolię z dawnymi koloniami, nie przynosi pożądanych efektów (integracja, współpraca gospodarcza i kulturowa). Wspólnota Narodów przestała odrywać dla państw członkowskich znaczącą rolę. Byłe brytyjskie dominia zaczęły przystępować do organizacji regionalnych (np. ANZUS - Pakt Bezpieczeństwa Pacyfiku). Wielka Brytania natomiast w latach 70. XX wieku podjęła wysiłki w celu uzyskania członkowska w Europejskiej Wspólnocie Gospodarczej (późniejsza Unia Europejska). Integracja Londynu $\mathrm{z}$ jego byłymi posiadłościami zamorskimi, pozostawała więc tylko ideą

11 Określenie używane w stosunku do Europy. Wprowadzone w okresie odkryć geograficznych dla rozróżnienia Nowego Świata, który swym zasięgiem obejmował obie Ameryki oraz Australię i Oceanię. 
daleką od rzeczywistości. O tym, że potrzebna jest odnowa popadającej w stagnację Wspólnoty Narodów świadczą liczne wypowiedzi wygłaszane przez angielskich decydentów. Jednym z krytyków obecnej sytuacji w Commonwealth był dyrektor organizacji DEMOS12, który w 2002 roku zaproponował, by królowa brytyjska udała się w „światowe tournee, żeby przeprosić za grzechy przeszłości Imperium, czyniąc pierwszy krok do uczynienia Wspólnoty Narodów (Commonwealth) efektywnym i znaczącym [stowarzyszeniem]" (Ferguson, 2007: 8). Taki gest mógłby przynieść korzystne efekty dla każdej ze stron. Byłe kolonie brytyjskie mogłyby stać się jeszcze większym rynkiem zbytu dla angielskich produktów eksportowych, Wielka Brytania natomiast stałaby się na arenie międzynarodowej rzecznikiem byłych kolonii, którego głos byłby lepiej słyszalny. Ważne jednak, by Wielka Brytania potrafiła zrehabilitować się za ponad 400 lat dominacji nad ludami podbitymi przez Imperium Brytyjskie. Pogłębienie stosunków gospodarczych i kulturowych jest więc konieczne, ponieważ bez realnej chęci pomocy państwom Trzeciego Świata Commonwealth stanie się „martwym tworem politycznym”.

\section{Bibliografia}

Bosacki, M. Ferguson: Imperiów żal. (http://wyborcza.pl/dziennikarze/1,84208,4092840. html, dostęp 30.06.2013).

Davis, M., Late Victorian Holocausts. El Nino Famines and the Making of the Third World. London and New York: Verso, 2002.

Ferguson, N., Imperium. Jak Wielka Brytania zbudowała nowoczesny świat. Warszawa: Sprawy Polityczne, 2007.

Report of the Indian Famine Commission, 1878. Government of India. Famine Relief, Londyn 1880.

Davis, M., Geneza Trzeciego świata. Rynek, państwo, klimat. (www.graniczne.amu.edu.pl/ PPGWiki/attach/.../davis_2010.doc, dostęp 18.04.2013).

Penier, I., Anglobalizacja czy narodziny Trzeciego Świata: Imperium Brytyjskie $w$ Indiach, artykuł nieopublikowany.

Manbiot, G., T. Maćkowski S. Brytyjski Holokaust. (www.lewica.pl/index.php?id=10316, dostęp 18.04.2013).

Włodek-Biernat, L., Chwała Bogu za Wielkq Brytanię!. (http://wyborcza.pl/1,89397, 4490633.html?as=3, dostęp: 12 VI 2013).

Rozdział VII. Imperializm jako odrębne stadium kapitalizmu. (www.marxists.org./polski/ lenin/1916/imperializm/10.htm dostęp 27.07.2013).

12 Niezależny brytyjski ośrodek badań opinii publicznej. 


\section{"The war of the words": The History of the British India in Neoliberal and Marxist Perspective}

Summary

More than 400 years of British domination over about a quarter of the land and the people of the world contributed to the creation of new states and nations. The world as we know it today was formed to a large extent by the phenomenon of "anglobalization". Many scholars can not take a decisive stance against British imperialism. For some, it entailed development of conquered colonies, for others their incorporation into the Third World. This article presents the history of British India in the nineteenth century from neoliberal and Marxist perspective. Neoliberal perspective is represented by the British historian Niall Ferguson, who, in his study Empire: How Britain Made the Modern World describes the benefits of colonization and ignores the mistakes of the British administration. Mike Davis, who represents Marxist outlook, in his book Late Victorian Holocausts: El Niño Famines and the Making of the Third World explicitly criticizes British imperialism. 